VARIA 


\section{Processo literário em sociedades desagregadas: o caso angolano}

Salete de Almeida Cara

Universidade de São Paulo

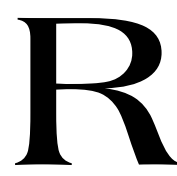

efletir sobre a literatura em Angola é estar diante de um caso exemplar. Já no folhetim precursor de Alfredo Troni, Nga Muturi, publicado como livro em 1882, a história é a de uma negrinha fula que vira escrava de branco, vendida pelo próprio tio para pagar um crime, em obediência ao que o branco invasor instituiu como "lei da terra". Concubina de seu proprietário e depois sua herdeira, ela se integra à vida da cidade, paga impostos, empresta a juros, quer distância da vida no mato e imagina um pai branco. A ascensão social da viúva ( $n g a$ muturi), no entanto, depende de um alto grau de humilhações que procurará esquecer. Dentre as piores, ser açoitada como os negros. "-Oh! Diabo! Matei o raio da preta" diz o patrão a certo momento. Em Castro Soromenho, mais de quarenta anos depois, vê-se que aquela "lei da terra", plantada no interesse do branco invasor, é resquício degradado de leis tradicionais arbitradas pelos antigos sobas, os chefes tribais, incorporados aos estratos mais baixos da administração colonial. ${ }^{1}$

A assimilação rebaixada da nga muturi faz parte do domínio violento sobre a gente da terra que, dessocializada e despersonificada, circulou como mercadoria a partir do século XVI, num processo que deu origem a um mosaico de etnias, essas instauradas pelos valores coloniais, e marginalizou negros e mulatos no processo de mestiçagem hipogâmica que, em Angola, incorporava o mulato desclassificado na comunidade dominada, a da mãe africana. E se violência e humilhação são indisso-

\footnotetext{
${ }^{1}$ Cf. Alfredo Troni, Nga Muturi. Lisboa, Ed. 70, 1973 e Fernando Monteiro de Castro Soromenho, Rajada e outras histórias. Lisboa, portugália, [s.d.].
} 
ciáveis da integração do país na economia-mundo, cada vez mais salta aos olhos sua exemplaridade no processo de constituição das formas de produção capitalista na periferia, onde revela sua face mais violenta. Não tenhamos ilusões quanto ao papel de uns e outros, pois só assim será possível rever, a despeito do mito da multirracialidade difundida pela ideologia colonial do "luso-tropicalismo", a generalidade do conceito de uma "fratria comunitária" entre Portugal, Angola e Brasil. ${ }^{2}$

Uma tal revisão levará, por certo, a um outra qualidade de diálogo entre os países do eixo sul, insistindo num atrito crítico com as formas imperialistas mais modernas. Por isso recupero essas histórias ficcionais, associadas que estão à longa experiência da exploração angolana. Primeiro os escravos, depois o café, petróleo e diamantes. A partir dos anos 30 do século XX, Portugal foi o mediador do acesso aos recursos naturais pelo capital internacional. Depois dos anos 70, esse capital financiava de um lado a guerrilha interna pós-Independência, mas de outro (e ao mesmo tempo) explorava o petróleo e os diamantes por todo o país, indicando que a Guerra Fria já tinha um vencedor. Capital que continuou atuando através do modelo econômico imposto pelo Consenso de Washington, adotado nos anos 90.

Refletir sobre a permanência dos enclaves capitalistas durante o governo de libertação socialista nos dá uma dimensão realista dos impasses que a experiência do presente oferece aos escritores angolanos. Não é de pouca monta a complexidade da matéria que vem soldando o romance angolano, até há pouco empenhado na construção de uma nação que, cada vez mais, serve melhor aos outros quanto pior está. Daí a urgência de repensar a qualidade do diálogo entre os países do eixo sul insistindo, mais até do que na tecla da fraternidade, na ampliação comum (e fraterna) de um atrito crítico com as formas imperialistas mais modernas. No campo literário, isso significa pensar se a adesão deslumbrada às teorias e técnicas literárias com prestígio em alta no mercado, o pouco interesse pelas questões práticas, sociais e econômicas,

${ }^{2}$ Cf. "Continuidade histórica do luso-tropicalismo", de Luis Felipe de Alencastro, onde encontramos a seguinte citação de Codórnega, o historiador luso-angolano do século XVII: "Aqui onde o filho é fusco/ E quase negro o neto,/ e todo negro o bisneto,/e tudo escuro". (São Paulo, Revista Cebrap no 32, março de 1992) 
a aposta na independência das realizações culturais, não seria uma resposta crédula às promessas do mercado, com as deserções que ele exige. ${ }^{3}$

As respostas são diversas e merecem exame. Dentre os romances escritos nos anos 90, o Nação Crioula - A correspondência secreta de Fradique Mendes (1977), de José Eduardo Agualusa, vem provocando especiais entusiasmos na área dos estudos pós-coloniais. Nesse engenhoso livro, Agualusa põe em cena algumas cartas supostamente perdidas da personagem de Eça de Queirós, cartas que revelam seu caso de amor com a angolana Ana Olímpia, em Angola e no Brasil. Se as cartas da "quase personagem" de Eça de Queirós em A Correspondência de Fradique Mendes não eram datadas, pois o Fradique de Eça prescindia de enredo e de topologia, em Agualusa elas se encaixam no período que vai de maio de 1868, quando Fradique desembarca em Angola, a outubro de 1888, quando está em Paris. Uma última carta, a única de Ana Olímpia, é dirigida a Eça de Queirós em 1900 já depois da morte de Fradique, conferindo alguma espessura de trama ao romance e sustentando o interesse episódico do leitor. Mas a chave do sucesso são os recursos usados por uma certa imaginação contemporânea que encontra, nas idiossincrasias de um diletante do século XIX, o seu mais perfeito complemento. ${ }^{4}$

A tecla principal de Agualusa é a possibilidade de reunião fraterna de países como Portugal, África e Brasil, num ideário transcultural e

3 "O controle, por exemplo, sobre a política de investimentos das empresas privadas atuantes no "enclave", sobre o volume de petróleo produzido e comercializado, sobre os preços praticados e sobre variáveis internas, como a folha de salários ou a estrutura de benefícios, era praticamente nenhum". Cf. Solival Meneze,. Mamma Angola (sociedade e economia de um país nascente). São Paulo, Edusp/Fapesp, 2000, p. 324. Cf. tb Luis Felipe de Alencastro, O trato dos viventes ( formação do Brasil no AtlânticoSul ). São Paulo, Companhia das Letras, 2000.

${ }^{4}$ Sobre o Fadique Mendes de Eça de Queirós escreve Antonio Candido: "O mundo, para ele, não é o material que se transforma e sobre o qual age a vontade do homem criador, - isto é, do Segundo Fausto; mas uma simples ocasião e quase um instrumento de cultivo do próprio Eu. Quem lhe dá esse domínio sobre o mundo é a civilização burguesa: insturmentos, aparelhos, veículos, invenções de toda espécie se adicionam à sua pessoa como atributos de onipotência e ubiqüidade." (Antonio Candido, "Entre campo e cidade", in Tese e Antítese. Rio, Companhia Editora Nacional, 1978, 3 ed., p. 39) 
transracial a gosto da crítica que ali também descobre procedimentos formais pós-modernos. Retomando seus termos elogiosos: Nação Crioula defende uma identidade coletiva Angola-Portugal, sendo o Brasil a alegoria do paraíso onde se cruzariam os destinos dos três países crioulos; o romance agita a bandeira das relações inter-raciais, e não mais a defesa da bandeira da negritude, através da idéia de pluralismo cultural; essa utopia fundadora de um imaginário comum encontraria, no procedimento da intertextualidade, o caminho mais conveniente; este pastiche do romance de Eça de Queirós expõe, portanto, uma política celebratória do multiculturalismo. ${ }^{5}$

Com intuito polêmico, no entanto, digo que o resultado literárioformal deste romance fica rebaixado justamente pela insuficiência pósmoderna do trato com a matéria, programaticamente dissolvida entre um passado que poderia ter sido - e que não foi - e uma promessa sem fundamento de futuro, com o auxílio explícito de dois clichês ideológicos, a cultura e a raça. Não há neste romance nenhum ímpeto utópico: nenhuma visão anti-hegemônica do mundo, nenhuma crítica radical, nenhuma radicalidade formal. Justamente porque a fratura social é recalcada, as formas do "marketing" liberal são reproduzidas de tal modo, que as personagens - do traficante de negros ao abolicionista brasileiro José do Patrocínio - se equivalem como iguais. Esse jogo de enganos, repetindo as ilusões de paridade entre moedas mais fracas e mais fortes, impulsiona a circulação ágil e sedutora do romance entre leitores curiosos e especializados. O modo narrativo epistolar, gênero fragmentário e aqui de mão única, como em Eça de Queirós, já que as cartas não têm resposta, garante a superficialidade de ocasião ao que é contado por Fradique, com segurança e verve, dando espaço a seus arroubos emotivos: boa dose de lirismo retórico nas cartas que escreve à amada, cor local e dados pitorescos dos costumes e figuras angolanos, nas cartas à Eça e Mme de Jouarre.

${ }^{5}$ Cf . Isabel Pires de Lima, "Pontes queirosianas: Angola, Brasil e Portugal", in Ecos do Brasil. Eça de Queirós. Leituras Brasileiras e Portuguesas, org. Benjamin Abdala Junior. São Paulo, Editora Senac, 2000; Maria Luiza Leal, "Recyclage culturel d' un voyageur; ouevre révolutionnarie, littérature postmoderne et poscolonial", in The paths of Multiculturalism. Travel writtings and postcolonialism. Lisboa, Edições Cosmos, 2000: Silvio Renato Jorge, "Uma trama de referências: o Fradique Mendes de Nação Crioula", in Revista Metamorfoses 2. Rio, UFRJ/Edições Cosmos e Cátedra Jorge de Sena, 2001. 
O trânsito internacional do Fradique eciano, que o livrava de compromissos duradouros, ensaia breve suspensão em Agualusa, que procura transformar Fradique Mendes em personagem de romance através do um caso amoroso. No movimento, o diletantismo de Fradique em Naçâo Crioula não só se confirma como se desdobra, com conseqüências, que vão da europeização da negra angolana ao tratamento pitoresco das personagens e costumes. Apenas um exemplo, o próprio modo como Fradique adere ao abolicionismo no Brasil, que mal disfarça a suposta boa intenção do escritor em relação à personagem que retoma : "parece que encontrei neste país uma nova causa com que entreter o espírito e afastar o ócio”. Não há distanciamento irônico. Ana Olímpia é a linda angolana filha de uma escrava e de um requintado príncipe congolês, ela mesma antiga escrava sem carta de alforria, mulher de grandes dotes intelectuais, que se torna uma das pessoas mais poderosas de Angola depois de viúva (nga muturi, como a personagem do folhetim de Troni, de quem se distingue pela origem e formação). A formação de Ana Olímpia é toda ela européia e, como seu pai, fala perfeitamente o português, além do francês. Lê Kant e Confúcio, conhece a moderna lírica francesa, organiza saraus para discutir a abolição, é proprietária exemplar - destaca-se dentre os "filhos do país" (os "mestiços e alguns negros calçados") e homens do mato. É ser de exceção complementar a Fradique, com quem forma o par perfeito.

Os contrabandistas que enriquecem "comprando e vendendo a triste humanidade" são, por sua vez, simpáticas figuras. Em chave pitoresca, aparece a favor do primeiro marido de Ana Olímpia, grande proprietário leitor de Proudhon e Baudelaire, o fato de ter batizado Liberdade, Igualdade e Fraternidade seus navios negreiros. Arcenio de Carpo, comerciante de escravos, tem função precisa nos bons resultados da relação do português com a africana: empresta ao casal seu belíssimo palacete colonial em Olinda, traz as boas novas da gravidez de Ana, que dará à luz uma menina mulata, Sophia, nascida no engenho Cajaíba que Fradique compra no Brasil. As opiniões de Arcenio sobre o comércio negreiro tem como contraponto apenas uma outra opinião do missivista, em ironia tão leve quanto inconseqüente. É com o filho de Arcenio que a angolana se casará depois da morte de Fradique. Pendor humanitário e interesses comerciais são atributos de todos e convivem com civilidade. A nga muturi de Agualusa não será jamais tratada por um patrão branco como "o raio da preta", tal como estava no romance de Alfredo Troni. 
Segundo afirmações de Agualusa em entrevista, a liberdade da personagem Fradique teria sido maior do que a do próprio Eça de Queirós, pois "o final do século XIX é um tempo de passagem, de dúvidas, e de ideologia colonial'. O escritor contemporâneo se sente a salvo de amarras ideológicas e preconceitos, e por isso afirma estar mais próximo de Fradique do que de Eça, o que lhe permitiria imaginar mais livremente do que teria sido possível ao escritor português. A notícia da morte de Fradique repete textualmente o livro de Eça de Queirós, compondo a figura com a qual afirma se identificar: "Cheios de idéias, de delicadas ocupaçôes e de obras amáveis, decorreram os derradeiros anos de Fradique Mendes em Paris, até que no inverno de 1888 a morte o colbeu sob aquela forma que ele, como César, sempre apetecera-inopinatam ataque repentinum (...)" 6

Mas o que Agualusa mantem de A Correspondência de Fradique Mendes? Há transformações? Quais seriam os resultados se comparássemos as posições do próprio Agualusa como intelectual e escritor com as de Eça de Cartas da Inglaterra, escritas entre 1880 e 1882 para o jornal A Gazeta de Notícias do Rio de Janeiro, onde tratando vigorosamente de questões como imperialismo e capitalismo para leitores brasileiros, o escritor português abria uma fecunda possibilidade crítica das interações comunitárias? Seria bom assinalar vivamente que, ao contrário de Eça, o escritor contemporâneo manifesta um assombroso apreço pelo seu próprio tempo presente, sem nenhuma negatividade. Um deslumbramento a quem nem mesmo era dado o diletante Fradique, com sua superioridade um tanto "blasé".

Fradique Mendes de 1900 exalava o senso estético apurado e expandido que, no seu tempo, dava em esteticismo - viés estetizante da vida e da literatura, forjando uma subjetividade cultivada como privilégio. Um tipo social bastante comum na França, que se horrorizava com a "infecção da banalidade" pela democratização das massas e defendia as "invioláveis liberdades do espirito", desprezando um mundo abjeto por

${ }^{6}$ Cf. entrevista de Agualusa em http:/www.terravista.pt/Baía-Gatas/1905/, onde afirma: "Dá-se o caso de Fradique, criatura de Eça, ser melhor, mais livre que o criador. É uma personagem muito aberta, muito receptiva à cultura dos outros."

Cf. José Eduardo Agualusa, Nação Crioula,. Rio, Gryphus, 1999, p. 135. 
reunir meros interesses em negócios e demandas populares. No entanto, assinale-se, é como mais uma mercadoria - o modelo do burguês ultracivilizado - que esse homem superior se oferece ao mundo que afirma desprezar.

Desde sua primeira aparição em O mistério da Estrada de Sintra, que Eça escreve com Ramalho Ortigão, sabe-se que Fradique Mendes é um "gentleman", um "filósofo de boulevard" famoso em Paris, um dândi requintado com seu criado inglês que, em 1870, quer ir para a França "ver os campos de batalha ao luar, ou aos archotes", esperando encontrar "atitudes de mortos muito curiosas". Em 1900, aquele Fradique realizava o ideal diletante de circulação internacional livre e superior, desimpedido de qualquer chão fixo: é um cosmopolita requintado, um "ser de exceção" que se exibe confiante. Mas até que ponto a atitude de Fradique é ratificada pelo escritor? Até que ponto, na seqüência do seu combate por um Portugal moderno e sem atraso exposto nos primeiros romances, não há em A Correpondência de Fradique Mendes uma nova atitude narrativa? Pois se ali não temos propriamente uma estrutura de romance, ainda assim é possível rastrear como o prefaciador e o missivista Fradique são expostos com distanciamento. Uma leitura cuidadosa fará ver que o tipo diletante Fradique Mendes, é antes uma figura do tempo e um problema.

Basta lembrar que dois anos antes, quando Carlos da Maia e João da Ega tinham voltado a Lisboa, em Os Maias, a experiência cosmopolita parecia livrar os dois amigos do ridículo daqueles rapazes do Passeio Público com suas pontudas botas à francesa. Mas as caçoadas de Maia e Ega não disfarçam a existência falida dos dois diletantes. Depois virá a obra-prima de Eça, e em A Ilustre Casa de Ramires o diletantismo de Gonçalo não é mais do que atribuição de outras personagens ( "Desandou em janota!' ) - vozes diversas que, sobretudo depois que Ramires parte para uma "vaga África" com "entusiasmo de fundador de império", assumem ao lado de um narrador ironicamente distanciado, a responsabilidade pelas opiniões e expectativas variadas, que são as do próprio tempo, construindo um painel de tons épicos mas ainda assim rebaixado.

Em Nação Crioula, a África é unanimidade sempre curiosa, e a conciliação geral tarefa já inscrita num passado histórico. Mas é isso o que tem a oferecer uma imaginação moderna e sua promessa de futuro? Uma imaginação que parece ter absorvido e generalizado a disposição otimista do antigo diletante, sem se dar conta de que ele é figura caricata das promessas não cumpridas da modernidade burguesa. Se tivesse sido 
irônico batizar "nação crioula" o violento traslado comercial dos negros, outro poderia ser o resultado narrativo do romance de Agualusa. Mas outro também seria o Fradique que surge de suas páginas, e quem sabe à altura do viés crítico e desassombrado de Eça de Queirós. No entanto, o filtro pósmoderno do escritor angolano banha o século XIX (mas sobretudo o seu próprio século) de benesses trans-históricas e trans-topológicas, fazendo tábua rasa do passado e expondo não uma utopia, mas uma fantasmagoria subjetiva. Respondendo com obediência as regras do jogo do mercado, sem forças para denunciar o que está sendo soterrado por ele, aqui não cabem problemas que possam perturbar os leitores no seu aplauso comum. Enquanto isso, desigualdades, exclusões e miséria dão o tom no cenário mundial.

\section{Referências Bibliográficas}

AGUALUSA, José Eduardo. Nação Crioula. Rio de Janeiro: Gryphus, 1999.

ALENCASTRO, Luiz Felipe de. Continuidade histórica do luso-tropicalismo. Revista Cebrap, São Paulo, n. 32, 1992.

MENEZES, Solival. Mama Angola (Sociedade e Economia de um país nascente). São Paulo: Edusp/Fapesp, 2000.

\section{Resumo}

Considerando a desagregação desigual e combinada dos países periféricos, no contexto do capital mundializado, este ensaio analisa o romance de José Eduardo Agualusa, Nação Crioula, e sua recepção crítica, observando de que modo os critérios do mercado cultural foram transformados em critérios literários e críticos.

\section{Resume}

En considérant la désagregation combinée mais pas égale des pays péripheriques, dans le monde globalisé, cet essai fait l'analyse du roman de José Eduardo Agualusa, Nação Crioula, et de sa réception critique, pour voir comment les critères du marché culturel ont été transformés en critéres litéraires et ausssi critiques. 